Pesq. Vet. Bras. 37(5):485-490, maio 2017

DOI: $10.1590 / \mathrm{S} 0100-736 \mathrm{X} 2017000500010$

\title{
Pythiosis in dogs in the semiarid region of Northeast Brazil ${ }^{1}$
}

\author{
Maria T.S. Frade ${ }^{2 *}$, Paula V.N. Diniz ${ }^{3}$, Roberio G. Olinda ${ }^{2}$ Lisanka A. Maia ${ }^{2}$ Glauco J.N. \\ de Galiza ${ }^{4}$, Almir P. de Souza², Pedro I. da Nóbrega Neto ${ }^{2}$ and Antônio F.M. Dantas ${ }^{2}$
}

\begin{abstract}
Frade M.T.S., Diniz P.V.N., Olinda R.G., Maia L.A., Galiza G.J.N., Souza A.P., Nóbrega Neto P.I. \& Dantas A.F.M. 2017. Pythiosis in dogs in the semiarid region of Northeast Brazil. Pesquisa Veterinária Brasileira 37(5):485-490. Hospital Veterinário, Laboratório de Patologia Animal, Centro de Saúde e Tecnologia Rural, Universidade Federal de Campina Grande, Campus de Patos, Av. Universitária s/n, Bairro Santa Cecília, Patos, PB 58708-110, Brazil. E-mail: talita_frade@hotmail.com

We describe the epidemiological, clinical and pathological features of five cases of pythiosis in dogs in northeast semiarid. The disease occurred in dogs with age between one and three years, females and males of different breeds. The dogs were created in urban areas, but were occasionally taken to the countryside and then had contact with wetlands. The main clinical signs were weight loss, vomiting, diarrhea and tenesmus. Macroscopically there were intestinal wall thickening with irregular firm masses with yellowish granular areas interspersed with a whitish tissue, involving the duodenum, colon and rectum, extending to the lymph nodes and pancreas, and the vagina and liver. In the skin there were areas of alopecia and irregular ulcerations, some containing small cavitations with serosanguineous secretion. Microscopically there were pyogranulomatous inflammation and in one case also there were eosinophilic necrosis associated with negative images tubuliformes by hematoxylin and eosin, strongly stained by GMS and weakly by PAS. Hyphae were strongly marked by immunohistochemistry with polyclonal anti-Pythium insidiosum. The disease occurs sporadically in dogs in the semiarid Northeast, however should be included in the differential diagnosis of chronic diseases and proliferative aspect of the gastrointestinal system, and front skin lesions of difficult treatment.
\end{abstract}

INDEX TERMS: Pythiosis, dogs, Pythium insidiosum, granuloma.

RESUMO.- [Pitiose em cães na região semiárida do Nordeste, Brasil.] Descrevem-se os aspectos epidemiológicos, clínicos e patológicos de cinco casos de pitiose em cães na região semiárida do Nordeste. A doença ocorreu em cães com idade entre um e três anos, fêmeas e machos, de diferentes raças. Os cães eram criados em zona urbana, mas ocasionalmente eram levados para zona rural e tinham contato com áreas alagadas. Em um caso não havia informações no histórico sobre acesso à zona rural. Os principais sinais clínicos observados foram perda de peso, vômito, diarreia e tenesmo.

\footnotetext{
${ }^{1}$ Received on July 19, 2015.

Accepted for publication on July 15, 2016.

${ }^{2}$ Programa de Pós-Graduação em Medicina Veterinária, Universidade Federal de Campina Grande (UFCG), Av. Universitária s/n, Bairro Santa Cecília, Patos, PB 58708-110, Brazil. *Corresponding author: talita_frade@ hotmail.com

${ }^{3}$ Graduando(a), Unidade Acadêmica de Medicina Veterinária (UAMV), Universidade Federal de Campina Grande, Patos, PB 58708-110, Brazil

${ }^{4}$ Docente da UFCG, Av. Universitária s/n, Bairro Santa Cecília, Patos, PB 58708-110, Brazil.
}

Macroscopicamente havia espessamento da parede do intestino com massas firmes, irregulares, com áreas granulares amareladas entremeadas por tecido esbranquiçado, no duodeno, cólon e reto, que se estendia ao pâncreas e linfonodos, além de fígado e vagina. Na pele havia área de alopecia e ulcerações irregulares, algumas contendo pequenas cavitações com secreção serosanguinolenta. Microscopicamente havia inflamação piogranulomatosa e em um caso também havia necrose eosinofílica associada a imagens negativas tubuliformes pela hematoxilina e eosina, fortemente impregnadas pelo GMS e fracamente coradas pelo PAS. As hifas foram fortemente imunomarcadas pela imuno-histoquímica com anticorpo policlonal anti-Pythium insidiosum. A doença ocorre esporadicamente em cães no semiárido nordestino, entretanto deve ser incluída no diagnostico diferencial das doenças em cães com evolução crônica e proliferativa que acometem o sistema gastrintestinal, e frente a lesões cutâneas de difícil tratamento.

TERMOS DE INDEXAÇÃO: Pitiose, caninos, Pythium insidiosum, granuloma. 


\section{INTRODUCTION}

Pythiosis is caused mainly by Pythium insidiosum, an oomycete of the kingdom Stramenopila (Fernandes et al. 2012), affects several species of domestic animals, wildlife and humans (Camus et al. 2004, Rakich et al. 2005, Santurio et al. 2006, Martins et al. 2012). The equine species is the most affected, followed by the dogs (Leal et al. 2001, Santurio et al. 2006, Torres Neto et al. 2009). P. insidiosum was considered as the only etiologic agent of Pythiosis in mammals (Gaastra et al. 2010), when Calvano et al. (2011) reported a case invasive infection in human in Afghanistan caused by P. aphanidermatum, after injury. And one other strain isolated in a dog Africa suggests that the causative agent of the disease represents a new species within the genus Pythium (Rivierre at al. 2005).

The occurrence of disease is mainly related with the contact of small wounds with contaminated water by mobile zoospores, which is the infective form of the agent or other propagules, zoospores or hyphae (Gaastra et al. 2010), however, Vanittanakom et al. (2014) confirmed by molecular techniques the presence of $P$. insidiosum soil.

In dogs the disease is characterized by the occurrence of cutaneous/subcutaneous and/or gastrointestinal lesions (Pereira et al. 2010, Martins et al. 2012), the latter being most common (Santurio et al. 2006). The gastrointestinal tract lesions are characterized by thickening of the wall of the stomach and intestine (Trost et al. 2009, Fernandes et al. 2012), and may occur great masses with involvement by extension to the pancreas, mesentery, lymph nodes, liver, uterus and prostate (Miller 1985, Jaeger et al. 2002, Grooters \& Foil 2012). There are also reports of mass in the esophagus, the oropharyngeal region and larynx (Patton et al. 1996, Helman \& Oliver 1999).

Infections $P$. insidiosum are often diagnosed in farm animals in the routine of Animal Pathology Laboratory, Veteri- nary Hospital of the Federal University of Campina Grande, LPA/HV/UFCG, causing skin lesions in equidae, sheep and goats (Tabosa et al. 1999, Tabosa et al. 2004, Pessoa et al. 2014, Carmo et al. 2015). In sheep also observed nasal and digestive forms (Portela et al. 2010, Pessoa et al. 2012). However, there is no report of infection in dogs in the Northeast. Thus, the aim of this study was to describe the main epidemiological, clinical and pathological findings of Pythiosis in dogs occurred in the semiarid region of the Northeast.

\section{MATERIALS AND METHODS}

Were identified and separated the cases of pythiosis in dogs diagnosed in LPA/HV/UFCG during the period from January 2011 to November 2014. Subsequently were collected epidemiological, clinical and macroscopic and microscopic aspects contained in the records of necropsy and biopsy.

The collected tissues were fixed in buffered formalin $10 \%$, cleaved, processed routinely and confectioned histological slides were stained with hematoxylin and eosin (HE). Histological sections were selected and also performed histochemistry techniques Grocott methenamine silver nitrate (GMS) and periodic acid-Schiff (PAS) for visualization of hyphae.

Has been selected a tissue fragment of each case and performed immunohistochemistry (IHC) with polyclonal antibody antiPythium insidiosum using the streptavidin-peroxidase complex and chromogen 3,3 diaminobenzidine (DAB). As a positive control, histological sections of confirmed case of Pythiosis in equine were used, and as a negative control, the same sections were used, with substitution of primary antibody by PBST.

\section{RESULTS}

Were diagnosed five cases of pythiosis, four from necropsy and one of biopsy. Epidemiological and clinical data, presentation form of disease and histopathological diagnoses are shown in Table 1.

Table 1. Epidemiological, clinical, affected organs, clinical presentation and histopathological diagnosis of canine Pythiosis diagnosed in LPA-UFCG

\begin{tabular}{|c|c|c|c|c|c|}
\hline Case & $\begin{array}{c}\text { Breed/ } \\
\text { Sex/ Age }\end{array}$ & $\begin{array}{l}\text { Origin/Access to } \\
\text { the rural areas }\end{array}$ & Clinical signs & $\begin{array}{l}\text { Affected organs/ } \\
\text { Form of disease }\end{array}$ & $\begin{array}{l}\text { Histopathological } \\
\text { diagnosis }\end{array}$ \\
\hline 1 & $\begin{array}{c}\text { Poodle } \\
\text { Female } \\
\text { 3,4-year-old }\end{array}$ & $\begin{array}{c}\text { Urban area } \\
\text { Paulista - PB/ } \\
\text { Yes }\end{array}$ & $\begin{array}{l}\text { Apathy, vomiting after } \\
\text { eating, tenesmus }\end{array}$ & $\begin{array}{l}\text { Duodenum, pancreas, } \\
\text { lymph nodes/Intestinal }\end{array}$ & $\begin{array}{l}\text { Enteritis, pancreatitis and } \\
\text { granulomatous lymphadenitis } \\
\text { with vasculitis and } \\
\text { fibrinoid necrosis }\end{array}$ \\
\hline 2 & $\begin{array}{c}\text { German } \\
\text { Shepherd Male } \\
\text { 1-year-old }\end{array}$ & $\begin{array}{c}\text { Urban area } \\
\text { Caicó - RN/Yes }\end{array}$ & $\begin{array}{l}\text { Ulcerated wound on the } \\
\text { base of the tail. Envolved } \\
\text { into hematoquezy }\end{array}$ & $\begin{array}{l}\text { Skin, anus, rectum, lymph } \\
\text { node/Cutaneous, and } \\
\text { subcutaneous Intestinal }\end{array}$ & $\begin{array}{l}\text { Dermatitis, panniculitis, } \\
\text { lymphadenitis and } \\
\text { granulomatous enteritis }\end{array}$ \\
\hline 3 & $\begin{array}{l}\text { Mixed breed } \\
\text { Female } \\
\text { 2,6-year-old }\end{array}$ & $\begin{array}{c}\text { Urban area } \\
\text { Parelhas - RN/ } \\
\text { Yes }\end{array}$ & $\begin{array}{l}\text { Hematochezia and } \\
\text { tenesmus }\end{array}$ & $\begin{array}{c}\text { Colon, rectum, anus } \\
\text { (mucocutaneous), perianal } \\
\text { gland, vagina, lymph nodes/ } \\
\text { Intestinal, Cutaneous and } \\
\text { Reproductive }\end{array}$ & $\begin{array}{c}\text { Enteritis, vaginitis, } \\
\text { lymphadenitis, adenitis and } \\
\text { granulomatous dermatitis }\end{array}$ \\
\hline 4 & $\begin{array}{l}\text { Pit bull } \\
\text { Female } \\
\text { 3-year-old }\end{array}$ & $\begin{array}{c}\text { Urban area } \\
\text { Patos - PB/N/I* }\end{array}$ & $\begin{array}{l}\text { Apathy, weight loss, } \\
\text { vomiting, hematochezia } \\
\text { and icterus }\end{array}$ & $\begin{array}{l}\text { Duodenum, pancreas, } \\
\text { lymph nodes, } \\
\text { liver/Intestinal }\end{array}$ & $\begin{array}{l}\text { Enteritis, pancreatitis, and } \\
\text { lymphadenitis perihepatitis } \\
\text { granulomatous, with } \\
\text { vasculitis, fibrinoid } \\
\text { necrosis and thrombosis }\end{array}$ \\
\hline 5 & $\begin{array}{c}\text { Poodle } \\
\text { Male } \\
\text { 1,8-year-old }\end{array}$ & $\begin{array}{l}\text { Urban area } \\
\text { Ouro Branco - } \\
\text { RN/Yes }\end{array}$ & $\begin{array}{l}\text { Hyporexia, weight loss, } \\
\text { hematochezia, tenesmus } \\
\text { and drowsiness }\end{array}$ & Colon/Intestinal & $\begin{array}{l}\text { Granulomatous enteritis, } \\
\text { necrotizing eosinophilic and } \\
\text { with fibrinoid necrosis } \\
\text { and thrombosis }\end{array}$ \\
\hline
\end{tabular}

*N/I = Non informed. 
In case 1 , the last contact with rural wetlands had occurred in April 2010, after 10 months the animal showed clinical signs of intestinal obstruction, characterized by vomiting in 2-3 hours after eating and tenesmus. Contrast radiography revealed partial obstruction of duodenum. Exploratory laparotomy showed swelling of duodenum and pancreas causing narrowing of the intestinal lumen. The adjacent area was adhered to the mesentery and dorsal abdominal wall.

In the second case, the animal presented with pruritic lesions in the tail for four months. Pythiosis was suspected and animal treated with intraconazole, cephalexin and meloxicam. A biopsy of the affected area was performed. Histopathology confirmed the diagnosis of pythiosis and a total caudectomy was performed. Antifungal therapy was maintained for 60 days after surgery (Torres et al. 2014). After 83 days of the day of surgery, the animal presented hematochezia and it was hypothesized that this was associated with the extent of the skin lesions. On exploratory laparotomy, enlargement and thickening of the rectal wall was observed.

Animal from case 3 presented hematochezia and tenesmus. Contrast radiography revealed narrowing of the colon wall. Colonoscopy was performed and hyperemic areas in the rectum and colonic ulcers were observed. Colon biopsy was performed and fungal colitis was diagnosed by histopathology. The animal was treated with systemic ketoconazole for 180 days. After this period, the animal still showed signs of tenesmus and exploratory laparotomy was perfor- med and segmental thickening of the colon and rectum wall were observed.

In case 4, the animal was presented with apathy, anorexia, weight loss, vomiting episodes after eating and melena within a progression of 90 days. After clinical examination, an exploratory laparotomy was elected, which revealed multiple areas of adhesion of omentum and mesentery to the intestine and liver.

In case 5 , the animal was presented with a 45-day history of hyporexia, hematochezia and weight loss. Exploratory laparotomy revealed thickening in the wall of the cecum and rectum. Resection and anastomosis of the middle third of the colon was performed and the sample submitted to histopathology. Pythiosis was diagnosed and the animal treated with ketoconazole.

Due the extension of the lesions, treatment failure and poor prognosis, euthanasia was performed in cases 1, 2, 3 and 4 . In case 5 , partial surgical resection associated with antifungal treatment showed favorable results. Six months after the end of the treatment the animal was healthy.

At necropsy, it was observed that the dogs 1, 3 and 4 were meager and with ocular and oral mucous pale. Animal 2 showed good body condition and caudectomia previously had been performed due the initial skin lesion.

Macroscopically, the lesions were similar and were characterized by irregular nodular masses firm, involving mostly intestine, pancreas and lymph nodes. In all cases there was of the intestine wall thickening with luminal stenosis.
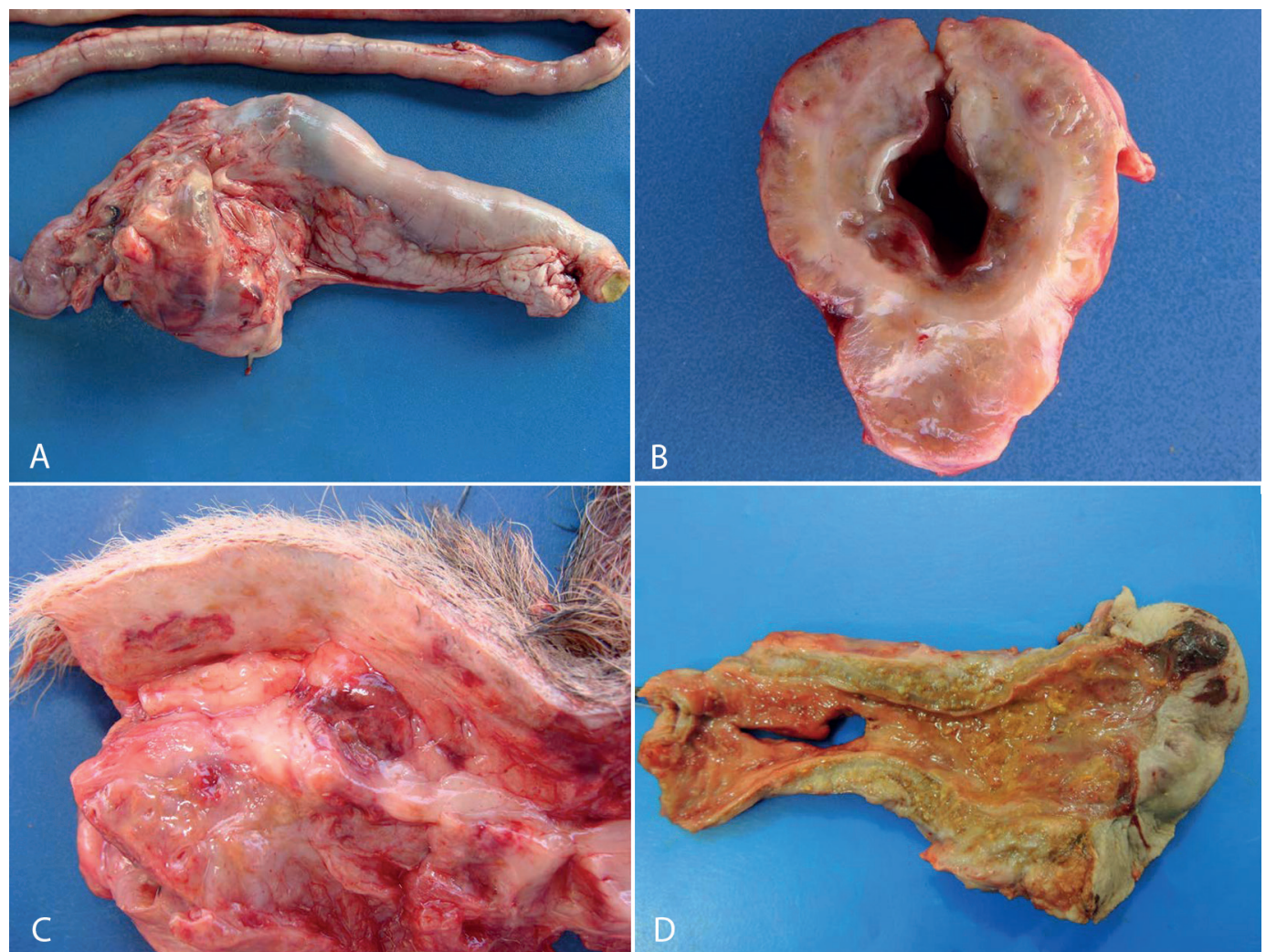

Fig.1. Pythiosis in dogs. (A) Irregular mass involving intestine, mesentery and pancreas. (B) Cross-sectional surface of the intestine showing thickening of the intestinal wall, with yellowish multifocal areas and stenosis of the lumen. (C) Thickening of the dermis and subcutaneous with multifocal areas the yellow coalescing interspersed with whitish tissue. (D) Thickening of the wall of the rectum and focal areas of ulceration in the mucocutaneous junction. 
In cross sections, there were areas multifocal to coalescing yellow and irregular granular, surrounded by whitish, smooth and shiny tissue, interspersed with brownish areas, affecting the duodenum initial portion (Cases 1 and 4), the end portion of the rectum (Cases 2 and 3 ) and the colon (Case 5). In cases 1 and 4, adjacent the intestinal wall thickening were seen irregular masses measuring 7 and $22 \mathrm{~cm}$ long, respectively, involving the duodenum, pancreas, mesentery lymph nodes and pancreas. In case 4 , there were also multiple adherences to the omentum and caudal region of the capsular surface of the liver.

Skin lesions were observed in case 2 and 3 . In case 2, was observed focally extensive area of alopecia and irregular ulcerations, some with small cavities containing secretion serosanguineous, extending the lumbar sacral region. At the cutting, subcutaneous thickening had multifocal areas containing the coalescing yellowish, slightly granular, ranging from 0.2 to $0.3 \mathrm{~cm}$ in diameter, surrounded by firm whitish tissue (Fig.1C). This lesion extended to adjacent musculature and final portion of the rectum and anus. In case 3 , in addition to primary intestinal lesion also had volume increase in perianal region (mucocutaneous junction), with multifocal ulcerated areas interspersed with reddish and yellowish areas and extended to the subcutaneous (Fig.1 D), perianal gland and serous vagina. Yellow-red areas were also seen on the wall and vaginal mucosa.

The microscopic lesions observed in all cases were similar, varying only in inflammatory response and were characterized by granulomatous reactions associated with areas of necrosis, containing hyphae not stained with hematoxylin and eosin. The affected organs have multifocal granulomas the coalescent, characterized by central areas of necrosis with neutrophil infiltration, many degenerate and periphery epithelioid macrophages, giant cells, and discrete lymphocytes, plasma cells and mild fibrosis. There was also moderate infiltration of eosinophils in the case 5. Associated with these areas of necrosis and also in the giant cells cytoplasm were observed tubuliformes structures in longitudinal and transverse sections, unstained (Fig.2A).

Granulomas were seen in the submucosa (Case 2 and 5), muscle and serosa (Case 1, 2 and 3) and only in the case serous 4 , and pancreas, lymph nodes, mesentery, the omentum, liver capsule and perianal gland. The lesion has occurred in the vagina transmural form (Case 3) and the skin (Case 2) involving the dermis, subcutaneous tissue and muscle surrounding. Vasculitis, fibrinoid necrosis and thrombosis were observed in three dogs (Case 1, 4 and 5).

In histological sections impregnated with the GSM, the wall of hyphae was stained strongly (Fig.2B), characterized by parallel walls, irregular ramifications, and sometimes forming straight angles with rare septa, measuring 4-10 $\mu \mathrm{m}$ in diameter. At the PAS the walls of the hyphae were stained weakly (Fig.2C). In IHQ performed on histological sections selected from each case there was a strong immunomarked for the wall and cytoplasm of hyphae Pythium insidiosum (Fig.2D).

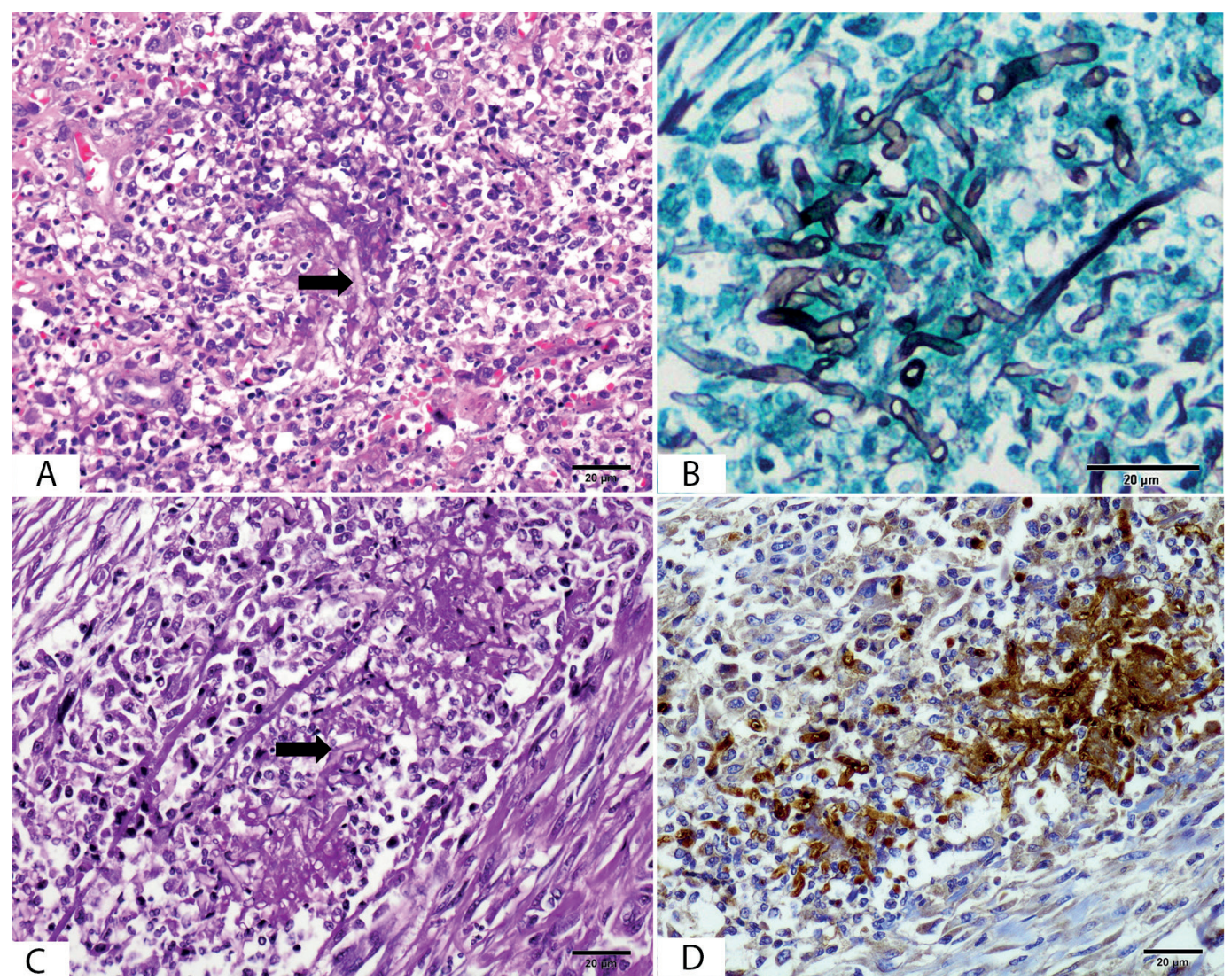

Fig.2. Pythiosis in dogs. (A) Negative image of hyphas Pythium insidiosum (arrow). HE. obj.20x. (B) Hyphas strongly impregnated black. GMS, obj.40x. (C) Hyphas slightly stained in red (arrow). PAS, obj.20x. (D) Hyphas brown strongly immunomarked by streptavidin-peroxidase method. Technical immunohistochemistry, obj.20x. 


\section{DISCUSSION}

The diagnosis of pythiosis was based on epidemiological, clinical and pathological findings, beyond the histochemical and morphological characteristics of the agent. The confirmation was made by immunohistochemistry, which is an effective and advantageous method, when unable to be performed culture or isolation of the agent (Trost et al. 2009). The disease occurred mainly in young dogs, regardless the breed and sex similar to that described by Fischer et al. (1994), differently from what was reported by Trost et al. (2009), where there was a higher occurrence in large sized males. Pythiosis traditionally found in tropical, subtropical and temperate regions (Gaastra et al. 2010), the five case studies occurred in the semiarid of Northeast Brazil that is characterized by having the dry and hot climate and the scarcity and irregular rainfall, however in four of five cases in this study the animals have contact with wetlands, which constitutes a risk factor for the occurrence of the disease, since preferably the agent inhabits aquatic environments which induces zoospore formation (Supabandhu et al. 2008). Although this condition was not informed in a dog (Caso 4), it is believed have occurred prior contact with the infective form of the agent for causing clinical disease. Berryessa et al. (2008) cites the occurrence of pythiosis in dogs at Arizona State, highlighting the vast difference between the arid climate of the southwestern United States and the tropical climates usually associated with the disease (A.M. Grooters, unpublished data). In this same paper, it is reported 10 cases of gastrointestinal pythiosis from California, in which seven of 8 dogs for which environmental data were available had frequent access to flooded rice fields or other water sources.

Some authors suggest that the disease occurs mainly in dogs bred in rural areas (Miller 1985, Fischer et al. 1994) and suburban areas (Fischer et al. 1994), however, it is important to highlight the occurrence of Pythiosis in dogs from urban environments, but which occasionally are taken to the rural areas and so has access to flooded environments, since the weirs and rivers in the semiarid region are also used as environments for leisure. It is believed that non-observation of cases of Pythiosis in rural setting dogs in this study, which would likely have a greater exposure to the agent, should be the low demand for specialized veterinary service.

The main clinical alterations observed in all dogs were related to primary or secondary involvement of intestine, due to granulomatous inflammation unleashed by the agent (Salas et al. 2009, Martins et al. 2012, Galiza et al. 2014), resulting in obstruction of the intestinal lumen. This is most commonly described clinical form of Pythiosis in dogs (Santurio et al. 2006), though that may occur sporadically the cutaneous form of the disease (Howerth et al. 1989, Torres Neto et al. 2009, Pereira et al. 2010). Noteworthy is the fact that in a case of primary colon involvement, there was the secondary involvement by extension of the reproductive tract, affecting the entire wall of the vagina. Similar cases, involving the reproductive system in dogs are less common, but have been reported affecting the uterus and prostate (Miller 1985, Jaeger et al. 2002, Grooters \& Foil 2012).
In two cases in this study were observed lesions on the skin and in the gastrointestinal tract, being an extension of the primary lesion in the final portion of the rectum affecting mucocutaneous region and the other secondary intestine was affected after the primary injury to the tail. The simultaneous occurrence of different skin and gastrointestinal lesions in the same animal is considered rare (Pereira et al. 2010).

In one of the cutaneous cases of this study, surgical removal of the affected area associated with antifungal therapy was not effective. The chronicity and extent of the injury, involving subcutaneous tissue and bowels might have determined the failure of the treatment. Surgical removal remains as the procedure of choice in controlling cutaneous pythiosis, however, surgical treatment shows good results only in small superficial lesions, in which the total removal of the affected area is doable (Leal et al. 2001). When there is gastrointestinal involvement surgical treatment is complicated by the need to remove large areas, and often, only partial resection is performed as observed in two cases of this study. In these cases, surgical removal was also complemented by the use of antifungal drugs, which was shown as an effective method in only one of the cases. Treatment with antifungal drugs is difficult because the target component of their mechanism is ergosterol, which is absent in the plasma membrane of oomycetes and consequently impairs their effectiveness (Foil 1996, Santurio et al. 2006). The success of treatment in one of the case was probably due to the initial stage of infection. Fujimori et al. (2016) also reported the efficacy of partial surgical enterectomy followed by itraconazole treatment in cases of colitis caused by Pythium insidiosum.

In areas where the disease occurs an endemic form, the Pythiosis should be included in the differential diagnosis of dogs with suspected intestinal obstruction, either chronic inflammation, neoplastic or foreign body, but also in cases of skin lesions difficult to treat. In the northeast region the disease is well known in farm animals, but it is uncommon in small animals.

\section{CONCLUSIONS}

Pythiosis occurs sporadically in dogs in the semi-arid northeast and should be included in the differential diagnosis of chronic and proliferative aspect of diseases that affect the gastrointestinal system, concomitant with stenosis or obstruction and the front of ulcerated skin lesions appearance and inefficient treatment.

The success of therapy can be determined by early diagnosis, location and extent of injury.

The prognosis in most cases is not favorable, especially in the gastrointestinal disease form in which there is involvement of large segments of the gastrointestinal tract.

\section{REFERENCES}

Berryessa N.A., Marks S.L., Pesavento P.A., Krasnansky T., Yoshimoto S.K., Johnson E.G. \& Grooters A.M. 2008. Gastrointestinal pythiosis in 10 dogs from California. J. Vet. Intern. Med. 22(4):1065-1069.

Camus A.C., Grooters A.M. \& Aquilar R.F. 2004. Granulomatous pneumonia caused by Pythium insidiosum in a central American jaguar, Panthera onca. J. Vet. Diagn. Invest. 16:567-571. 
Carmo P.M.S., Portela R.A., Silva T.R., Oliveira-Filho J.C. \& Riet-Correa F. 2015. Cutaneous Pythiosis in a Goat. J. Comp. Path. 152(2-3):103-105.

Calvano T.P., Blatz P.J., Vento T.J., Wickes B.L., Sutton D.A., Thompson E.H., White C.E., Renz E.M. \& Hospenthal D.R. 2011. Pythium aphanidermatum infection following combat trauma. J. Clin. Microbiol. 49(10):3710-3.

Fernandes C.P.M., Giordania C., Greccob F.B., Sallis E.S.V., Stainkic D.R., Gasparc L.F.J., Ribeiro C.L.G. \& Nobre M.O. 2012. Gastric pythiosis in a dog. Revta Iberoam. Micol. 29(4):235-237.

Fischer J.R., Pace L.W., Turk J.R., Kreeger J.M., Miller M.A. \& Gossner H.S. 1994. Gastrointestinal pythiosis in Missouri dogs: Eleven cases. J. Vet. Diagn. Invest. 6(3):380-382.

Foil C.S. 1996. Update on Pythiosis (Oomycosis). The North American Veterinary Conference 23:57-63.

Fujimori M., Lopes E.R., Lima S.R., Jesus de Paula D.A., Almeida A.B.P.F., Colodel E.M., Pescador C.A., Néspoli P.E.B., Nakazato L., Dutra V., Souza R.L. \& Sousa V.R.F. 2016. Pythium insidiosum colitis in a dog: treatment and clinical outcome. Ciência Rural 46(3):526-529.

Gaastra W., Lipman L.J.A., De Cock A.W.A.M., Exel T.K., Pegge R.B.G., Scheurwater J., Vilela R. \& Mendoza L. 2010. Pythium insidiosum: an overview. Vet. Microbiol. 146:1-16.

Galiza G.J.N., Silva T.M., Caprioli R.A., Barros C.S.L., Irigoyen L.F., Fighera R.A., Lovato M. \& Kommers G.D. 2014. Ocorrência de micoses e pitiose em animais domésticos: 230 casos. Pesq. Vet. Bras. 34(3):224-232.

Grooters A.M. \& Foil C.S.O. 2012. Micellaneous fungal infections, p.675688. In: Greene C.E. (Ed.), Infectious Diseases of the Dogs and Cats. 4th ed. Saunders Elsevier, St Louis.

Helman R.G. \& Oliver J. 1999. Pythiosis of the digestive tract in dogs from Oklahoma. J. Am. Anim. Hosp. Assoc. 35(2):111-114.

Howerth E.W., Brown C.C. \& Crowder C. 1989. Subcutaneous Pythiosis in a dog. J. Vet. Diag. Invest. 1(1):81-83.

Jaeger G.H., Rotstein D.S. \& Law J.M. 2002. Prostatic pythiosis in a dog. J. Vet. Intern. Med. 16(5):598-602.

Leal A.T., Leal A.B.M., Flores E.F. \& Santurio J.M. 2001. Pitiose: revisão bibliográfica. Ciência Rural 31(4):735-743.

Martins T.B., Kommers G.D., Trost M.E., Inkelmann M.A., Fighera R.A. \& Schild A.L. 2012. A Comparative Study of the Histopathology and Immunohistochemistry of Pythiosis in Horses, Dogs and Cattle. J. Comp. Pathol. 46:122-131.

Miller R.I. 1985. Gastrointestinal phycomycosis in 63 dogs. J. Am. Vet. Med. Assoc. 186(5):473-478.

Patton C.S., Hake R., Newton J. \& Toal R.L. 1996. Esophagitis due to Pythium insidiosum infection in two dogs. J. Vet. Intern. Med. 10(3):139-142.
Pereira D.I.B., Schild A.L., Motta M.A., Fighera R.A., Sallis E.S.V. \& Marcolongo-Pereira C. 2010. Cutaneous and gastrointestinal pythiosis in a dog in Brazil. Vet. Res. Commun. 34:301-306.

Pessoa C.R.M., Riet-Correa F., Pimentel L.A., Garino Júnior F., Dantas A.F.M., Kommers G.D., Tabosa I.M. \& Reis-Júnior J.L. 2012. Pythiosis of the digestive tract in sheep. J. Vet. Diagn. Invest. 24(6):1133-1136.

Pessoa A.F.A., Pessoa C.R.M., Miranda Neto E.G., Dantas A.F.M. \& Riet-Correa F. 2014. Doenças de pele em equídeos no semiárido brasileiro. Pesq. Vet. Bras. 34(8):743-748.

Portela R.A., Riet-Correa F., Garino Júnior F., Dantas A.F.M., Simões S.V.D. \& Silva S.M.S. 2010. Doenças da cavidade nasal em ruminantes no Brasil. Pesq. Vet. Bras. 30(10):844-854.

Rakich P.M., Grooters A.M. \& Tang K. 2005. Gastrointestinal Pythiosis in two cats. J. Vet. Diagn. Invest. 17(3):262-269.

Rivierre C., Laprie C., Guiard-Marigny O., Bergeaud P., Berthelemy M. \& Guillot J. 2005. Pythiosis in Africa. Emerging Infect. Dis.11(3):479-481.

Salas Y.J., Márquez A.A., Corro A.C. \& Colmenárez V. 2009. Caracterización macroscópica y microscópica de la pythiosis gastrointestinal de perros en Venezuela. Revta Fac. Cienc. Vet. 50(1):23-31.

Santurio J.M., Alves S.H., Pereira D.B. \& Argenta J.S. 2006. Pitiose: uma micose emergente. Acta Scient. Vet. 34(1):1-14.

Supabandhu J., Fisher M.C., Mendoza L. \& Vanittanakom N. 2008. Isolation and identification of the human pathogen Pythium insidiosum from environmental samples collected in Thai agricultural areas. Med. Mycol. 46(1):41-52.

Tabosa I.M., Medeiros V.T., Dantas A.F.M., Azevedo E.O \& Maia J.C. 1999. Pitiose cutânea em eqüídeos no semi-árido da Paraíba. Arq. Bras. Med. Vet. Zoot. 51(1):27-30.

Tabosa I.M., Medeiros V.T., Dantas A.F.M., Azevedo E.O. \& Maia J.C. 2004. Outbreaks of pythiosis in two flocks of sheep in Northeastern Brazil. Vet. Pathol. 41(4):412-415.

Torres L.M., Dantas A.K.F.P., Silva J.K.C., Araújo K.N., Garino Junior F. \& Mendes R.S. 2014. Pitiose cutânea canina: relato de caso. Ars Vet. 30(2):77-82.

Torres Neto R., Bosco S.M.G., Amorim R.L., Brandão C.V.S., Fabris V.E., Estanislau C. \& Bagagli E. 2009. Cutaneous pythiosis in a dog from Brazil. Vet. Dermatol. 21:202-204.

Trost M.E., Gabriel A.L., Masuda E.K., Fighera R.A., Irigoyen L.F. \& Kommers G.D. 2009. Aspectos clínicos, morfológicos e imuno-histoquímicos da pitiose gastrintestinal canina. Pesq. Vet. Bras. 29(8):673-679.

Vanittanakom N., Szekely J., Khanthawong S., Sawutdeechaikul P., Vanittanakom P. \& Fisher M.C. 2014. Molecular detection of Pythium insidiosum from soil in Thai agricultural areas. Int. J. Med. Microbiol. 304(3):321-326. 